\title{
DNA Damage Tolerance Mechanisms Revealed from the Analysis of Immunoglobulin V Gene Diversification in Avian DT40 Cells
}

\author{
Takuya Abe ${ }^{1,2}$, Dana Branzei ${ }^{2,3}$ and Kouji Hirota ${ }^{1, *}$ \\ 1 Department of Chemistry, Graduate School of Science and Engineering, Tokyo Metropolitan University, \\ Minamiosawa 1-1, Hachioji-shi, Tokyo 192-0397, Japan; 0330abe@tmu.ac.jp \\ 2 IFOM, the FIRC Institute of Molecular Oncology, Via Adamello 16, 20139 Milan, Italy; dana.branzei@ifom.eu \\ 3 Istituto di Genetica Molecolare, Consiglio Nazionale delle Ricerche (IGM-CNR), Via Abbiategrasso 207, \\ 27100 Pavia, Italy \\ * Correspondence: khirota@tmu.ac.jp
}

Received: 30 October 2018; Accepted: 30 November 2018; Published: 7 December 2018

\begin{abstract}
DNA replication is an essential biochemical reaction in dividing cells that frequently stalls at damaged sites. Homologous/homeologous recombination (HR)-mediated template switch and translesion DNA synthesis (TLS)-mediated bypass processes release arrested DNA replication forks. These mechanisms are pivotal for replication fork maintenance and play critical roles in DNA damage tolerance (DDT) and gap-filling. The avian DT40 B lymphocyte cell line provides an opportunity to examine HR-mediated template switch and TLS triggered by abasic sites by sequencing the constitutively diversifying immunoglobulin light-chain variable gene $(\mathrm{IgV})$. During $\operatorname{IgV}$ diversification, activation-induced deaminase (AID) converts $\mathrm{dC}$ to $\mathrm{dU}$, which in turn is excised by uracil DNA glycosylase and yields abasic sites within a defined window of around 500 base pairs. These abasic sites can induce gene conversion with a set of homeologous upstream pseudogenes via the HR-mediated template switch, resulting in templated mutagenesis, or can be bypassed directly by TLS, resulting in non-templated somatic hypermutation at $\mathrm{dC} / \mathrm{dG}$ base pairs. In this review, we discuss recent works unveiling $\mathrm{IgV}$ diversification mechanisms in avian DT40 cells, which shed light on DDT mode usage in vertebrate cells and tolerance of abasic sites.
\end{abstract}

Keywords: homologous recombination; translesion DNA synthesis; replication; activation-induced deaminase; abasic site; DNA damage

\section{Introduction}

Cellular DNA is continuously damaged by chemical and physical agents from both endogenous metabolic processes and exogenous insults. Replicative DNA polymerases replicate genomic DNA with extraordinarily high accuracy, making only a single error per $10^{6}$ nucleotides synthesized in vivo [1]. Due to this enzymatic property, replicative polymerases cannot accommodate nucleotides at damaged templates and thus arrest replication [2]. Cells employ several mechanisms for releasing arrested replication forks depending on the type of DNA lesions or the cell cycle phase [3]. One of the most common and formidable lesions is the abasic site. Abasic sites are estimated to occur at a frequency of over 10,000 sites per cell per day in mammalian cells [4,5]. These lesions can be repaired via accurate base excision repair [6-9]. However, when the replication fork encounters unrepaired abasic sites, they are dealt with by DNA damage tolerance (DDT) mechanisms that allow completion of replication beyond the damaged template and prevent formation of deleterious double strand breaks (DSBs) $[10,11]$. In general, there are two modes of DDT conserved in eukaryotes [10]. One mode is mediated through homologous recombination (HR), which mediates continuous replication using a 
newly synthesized sister strand [10,12,13] (Figure 1A). A second mode is translesion DNA synthesis (TLS), which employs specialized DNA polymerases, including polymerase $\eta$ and polymerase $\zeta$, to permit continuous replication beyond the damaged template [14-18] (Figure 1B).

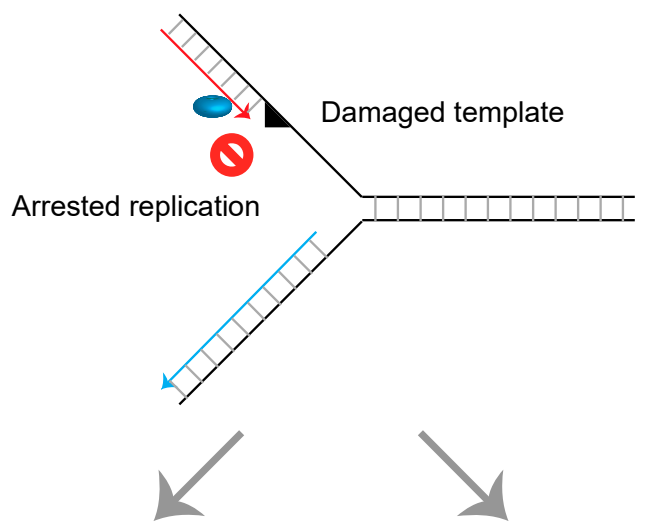

A: HR mediated template switch

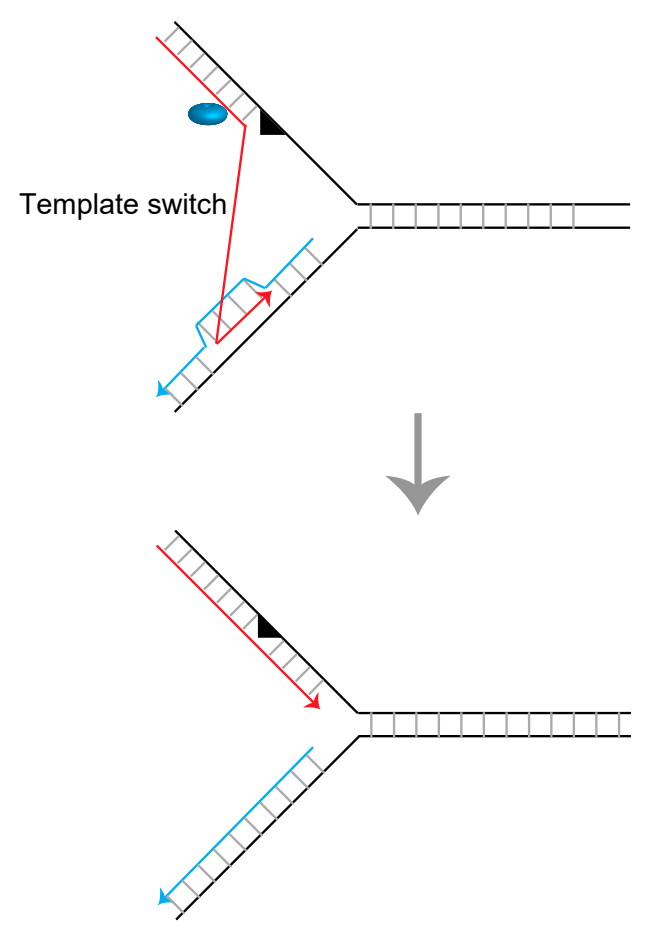

Error-free bypass replication
B: TLS polymerases mediated TLS
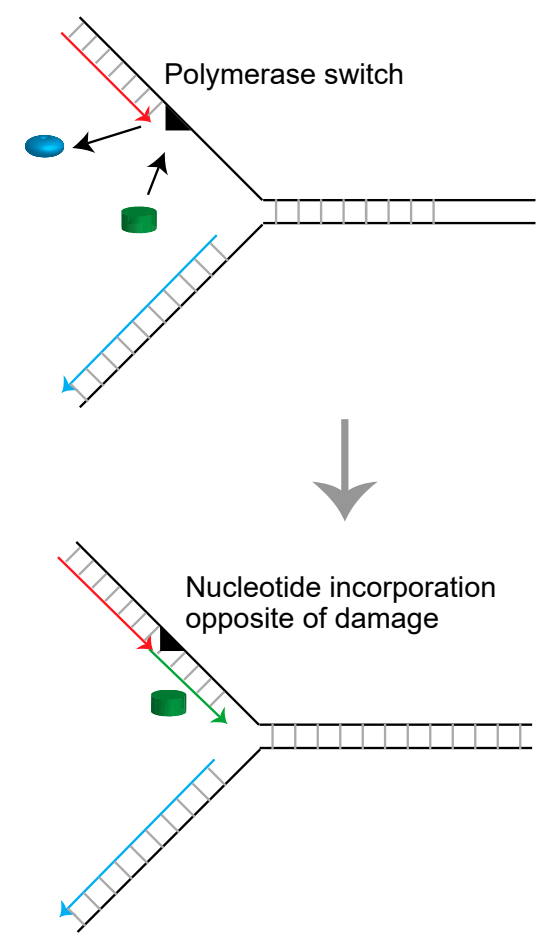

Error-prone bypass replication

Figure 1. Schematic representation of mechanisms releasing the arrested replication fork at the damaged template. (A) Homologous recombination (HR)-mediated template switch releases the arrested replication fork using intact newly synthesized DNA as the template strand and promotes error-free bypass replication. (B) Translesion DNA synthesis (TLS) polymerases mediate direct bypass replication across the damaged template in an error-prone manner. 


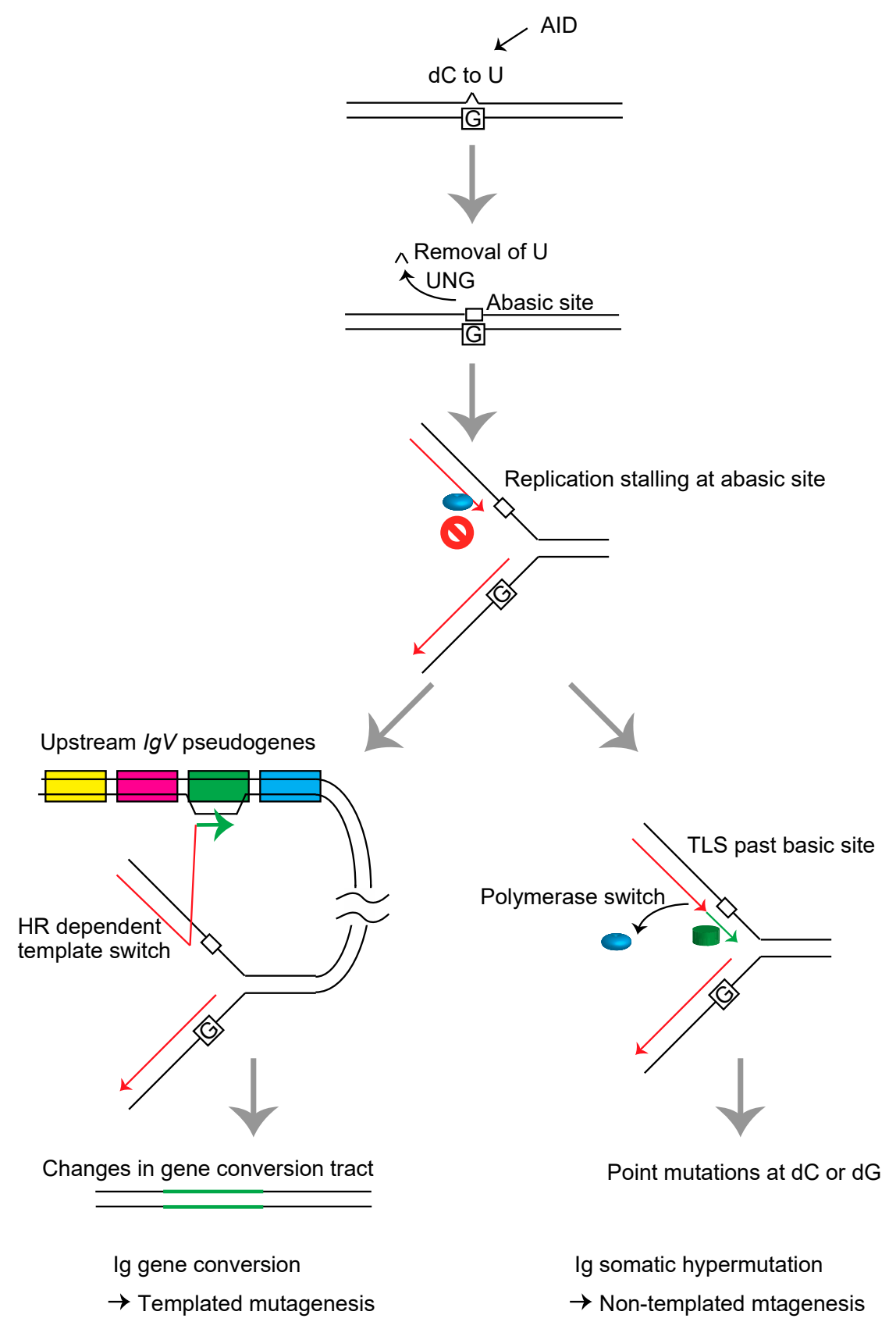

Figure 2. Schematic representation of the immunoglobulin variable $(\mathrm{IgV})$ gene diversification mechanism in DT40 cells. The sequential actions of activation-induced deaminase (AID) and uracil DNA glycosylase (UNG) induce abasic sites in the $I g V$ gene. The replication fork arrests at these lesions and induces template switch-mediated gene conversion with one of the 25 copies of upstream $\operatorname{IgV}$ pseudogenes carrying a $\sim 10 \%$ mismatch rate, resulting in HR-mediated diversification/mutagenesis of the immunoglobulin gene (left), or TLS, resulting in somatic hypermutation at the $\mathrm{dC} / \mathrm{dG}$ base pairs (right).

When the blocking lesions are abasic sites, DDT processes serve additional functions, such as generating immunoglobulin diversity in B cells $[19,20]$. Avian B cells diversify the immunoglobulin variable $(\operatorname{IgV})$ gene through HR-mediated gene conversion and TLS-mediated somatic hypermutation [21]. In the initiation process of $\operatorname{IgV}$ diversification, activation-induced deaminase (AID) leads to conversion of $\mathrm{dC}$ to $\mathrm{dU}$ on regions of single-stranded DNA, the exposure of which is locally facilitated by the histone variant H3.3 [22], probably because nucleosome cores containing H3.3 are more unstable than those containing canonical $\mathrm{H3}$ variants [23]. The uracil DNA glycosylase (UNG) efficiently excises the uracil residues, yielding a high frequency of abasic sites [24,25] within a defined 
window of around 500 base pairs. The restriction of AID-mediated abasic sites to the $\operatorname{IgV}$ gene is mediated by the cis-acting sequence referred to as DIVAC (diversification activator) [26]. The replication stalling at these abasic sites either induces template switch-mediated gene conversion with one of the 25 copies of upstream $\operatorname{IgV}$ pseudogenes carrying $10 \%$ mismatch, resulting in HR-mediated diversification/mutagenesis of the immunoglobulin gene, or they induce TLS, resulting in somatic hypermutation at the $\mathrm{dC} / \mathrm{dG}$ base pairs [14,15,24,27-31] (Figure 2). The induced hypermutations are most likely a consequence of replication bypass across abasic sites, rather than bypass of dU, as evidenced by the fact that most mutations are $\mathrm{dC} / \mathrm{dG}$ to $\mathrm{dG} / \mathrm{dC}$ transversions and loss of UNG instead leads to replication over the $\mathrm{dU}$, resulting in $\mathrm{dC} / \mathrm{dG}$ to $\mathrm{dT} / \mathrm{dA}$ transitions [24].

The avian DT40 cell line derived from bursal B cells continues to diversify its $\operatorname{IgV}$ gene by gene conversion and somatic hypermutation during in vitro passage [32]. This cell line exhibits extraordinarily high gene-targeting efficiency, as an exception among vertebrate cell lines, and it is thus used in genetic studies due to the relative ease of establishing mutants [33]. Using this cell line, a number of studies have assessed the contribution of genes of interest to HR-mediated template switch and TLS via analyzing $I g V$ diversification mechanisms [19]. Herein, we discuss how the DT40 cell line provides an opportunity to examine HR-mediated template switch and TLS at abasic sites via sequencing the constitutively diversifying $\operatorname{Ig} V$ gene.

\section{Immunoglobulin variable (IgV) Gene Diversification in DT40 Cells}

To examine $\operatorname{Ig} V$ sequence diversification within the limited duration of in vitro passage (usually $2-5$ weeks), the following methods increase the frequency of $\operatorname{Ig} V$ sequence diversification and allow effective measurement of the $\operatorname{Ig} V$ diversification rate.

The first method is treating DT40 cells with a histone deacetylase inhibitor, trichostatin A (TSA). This method increases the frequency of HR-mediated gene conversion 50- to 100-fold, with limited effects on TLS-mediated somatic hypermutation [17,34]. Thus, for evaluating HR efficiency, TSA treatment during in vitro passage of DT40 cells allows for sensitive detection of gene conversion events. The mechanism underlying TSA-mediated activation of gene conversion has not been fully elucidated, but a likely scenario is that TSA mainly affects the chromatin in the upstream $\operatorname{IgV}$ pseudogenes, favoring their open configuration. Subsequently, the HR machinery can efficiently induce gene conversion using these pseudogenes as donor sequences. This view is supported by the observation that tethering of the heterochromatin protein HP1 to upstream $\operatorname{IgV}$ pseudogene regions diminishes histone acetylation within this region and alters the outcome of $\operatorname{IgV}$ diversification, causing somatic hypermutation to outweigh gene conversion [35]. The efficiency of gene conversion events can be estimated without conducting sequence analysis. Specifically, the status of surface immunoglobulin $\mathrm{M}$ (sIgM) expression in DT40 cl-18 cells, which carry a frameshift mutation in the $\operatorname{Ig} V \lambda$ segment, alters from negative to positive (sIgM gain) by gene conversion-mediated replacement of the frameshift mutation. Thus, by measuring the rate of sIgM gain, the frequency of gene conversion can be estimated (Figure 3A). The percentage of sIgM-positive cells within expanding subclones can be analyzed by fluorescence activated cell sorting (FACS) [36].

Another method is AID overexpression during in vitro passage of DT40 cells. In this approach, mouse AID (mAID) is overexpressed via infection with retrovirus containing the $m A I D$ gene, followed by an internal ribosomal entry site and the GFP gene, as described previously [37]. With this method, the expression level of the mouse AID protein is approximately 20 times higher than that of endogenous chicken AID [38]. With the same methodology, chicken AID cannot be efficiently overexpressed, presumably due to protein level control (author's unpublished data). A variant of this method is to establish clones overexpressing an enzymatically hyperactive form of human AID, hAIDup 7.3 [39], which exhibits increased levels of deamination while generating an identical pattern of deamination to the wild-type enzyme [22,39]. 
A

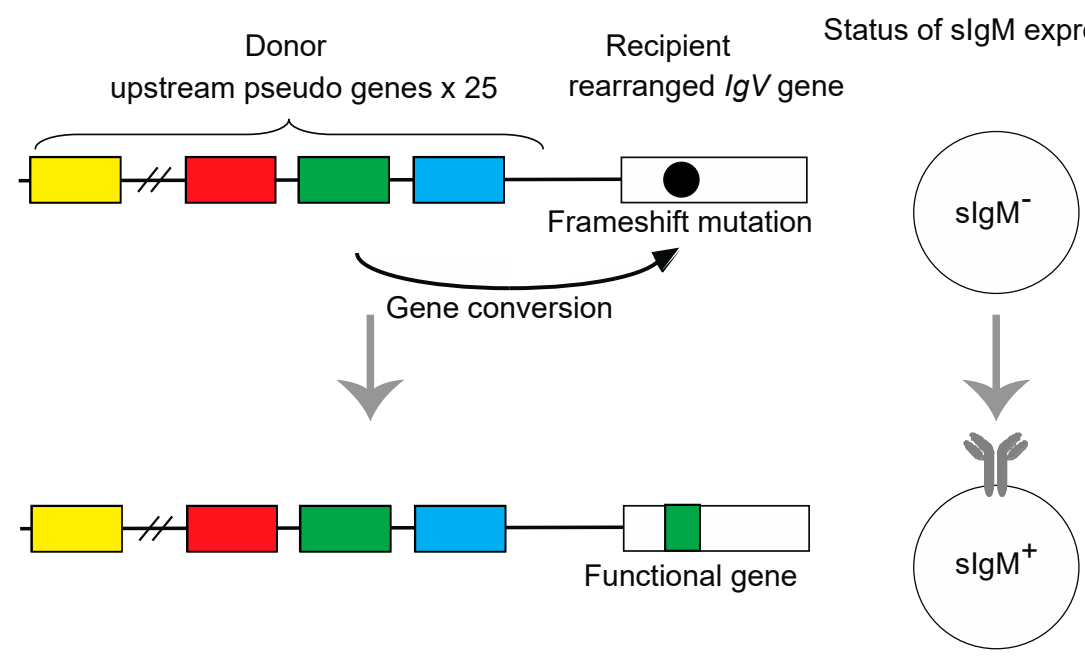

B
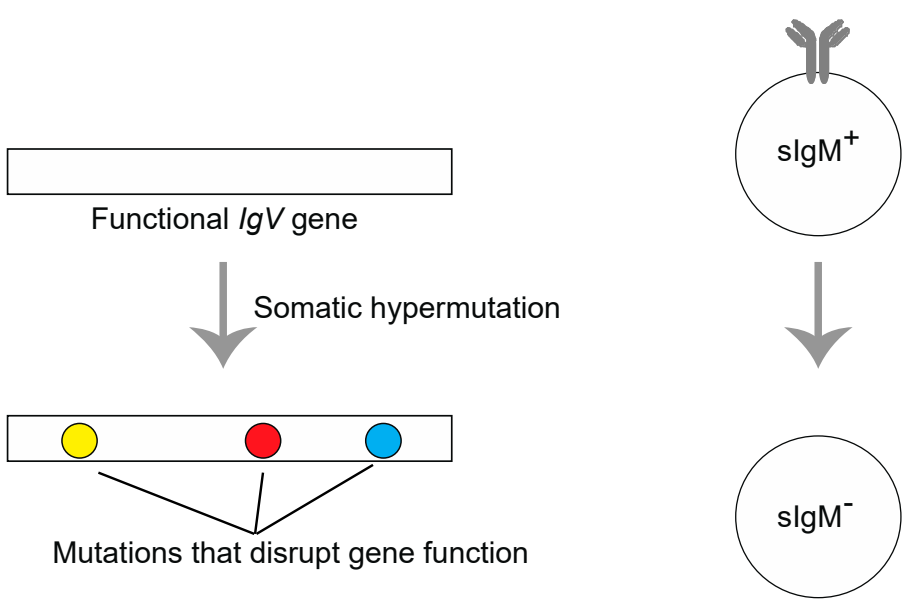

Figure 3. Schematic representations of the surface immunoglobulin $M(\operatorname{sig} M)$ gain (A) and $\operatorname{sigM} \operatorname{loss}$ assays (B). (A) Principle of the Ig gene conversion assay. The sIgM-negative DT40 clone contains a frameshift in its rearranged $V-J_{\lambda}$ segments, which can be repaired by pseudogene-templated conversion events. The rate of Ig gene conversion can be measured as a gain of sIgM expression in subclones by flow-cytometric analysis of sIgM staining. (B) Principle of the Ig hypermutation assay. The DT40 cells carrying wild type $\operatorname{IgV}$ gene, which can be disrupted by somatic hypermutation events. The rate of hypermutation events can be measured as a loss of sIgM expression in subclones by flow-cytometric analysis of sIgM staining. The sequence analysis of hypermutation event can be also carried out by selecting sIgM negative cells by cell sorter.

The overexpression of AID increases gene conversion at a rate similar to that of gene conversion induced by TSA [38]. Moreover, somatic hypermutation is significantly increased by AID overexpression, and hypermutation events are observed in nearly all $\operatorname{IgV}$ sequences analyzed, while somatic hypermutation is barely detectable without AID overexpression. AID overexpression induces gene conversion and somatic hypermutation at a ratio of approximately 1:2. AID overexpression during in vitro passage of DT40 cells allows sensitive detection of gene conversion and somatic hypermutation.

An alternative approach to analyze hypermutation events without AID overexpression has also been used. Instead of increasing the frequency of diversification, cells with spontaneously diversified 
$\operatorname{IgV}$ sequences can be selected by the status of sIgM expression using the cell sorter. Since the hypermutation-mediated insertion of deleterious mutations results in the loss of sIgM expression, starting from sIgM positive cells and selecting for sIgM negative cells is proposed to be a good readout of the hypermutation events. In support of this hypermutation-mediated sIgM loss is the observation that complete deletion of upstream pseudogenes $\left(\psi V^{-}\right)$diminishes gene conversion while increasing hypermutation events and the frequency of sIgM loss [28]. However, the caveat with this approach is that sIgM loss can also derive in good part from gene conversion-associated frameshift in wild type (WT) cells [40]. Thus, perhaps a good compromise in this regard would be to use a cell line with complete deletion of upstream pseudogenes $\left(\psi V^{-}\right)$and to approximate the sIgM loss with the frequency of somatic hypermutation events (Figure 3B).

Importantly, the hypermutation analysis allows evaluation not only of TLS efficiency but also of the mutation spectrum. In wild type cells, dG to dC transversion predominantly occurs [24], while in certain cases when TLS polymerase(s) are inactivated, the mutation spectrum is altered, possibly due to a shift of used TLS polymerase(s) in the bypass of replication across abasic sites in the $\operatorname{IgV}$ gene $[14,27,41]$.

Differentiating between hypermutation and gene conversion from the $\operatorname{Ig} V$ nucleotide sequence should be carried out as previously described [40]. Briefly, all sequence changes are assigned to one of the following three categories: hypermutation, gene conversion or ambiguous mutation. A single base substitution can be categorized as hypermutation or ambiguous mutation. Using the genome database search, if one can find pseudogenes identical to the sequence containing the point mutation, such mutation is categorized as ambiguous mutation, while if no identical donor sequence can be identified, such point mutation should be categorized as hypermutation. An event with multiple mutations having an identical pseudogene is interpreted as a single gene conversion event. If a sequence containing multiple substitutions is not completely identical to one of the pseudogenes, but has few mismatches, such mutations can be interpreted as deriving from a single gene conversion event followed by several subsequent hypermutations.

\section{Templated Mutagenesis by Gene Conversion}

Ig gene conversion is mediated through HR as evidenced by the fact that deletion of upstream homeologous $\operatorname{IgV}$ pseudogenes completely abolishes gene conversion [28] (Figure 4, Table 1, Pseudo V). This observation also demonstrates that gene conversion and hypermutation are initiated from a common DNA lesion mediated by AID, since loss of upstream $\operatorname{Ig} V$ pseudogenes activates AID-dependent hypermutation (Figure 4, Table 1). This idea is further strongly supported by the fact that in DT40 cells mutated in Rad51 paralog genes BRCA1 or BRCA2, in which recruitment of the Rad51 DNA-strand exchange protein to damaged DNA is strongly impaired [40,42,43], gene conversion is critically reduced and the $\operatorname{IgV}$ diversification is strongly shifted toward hypermutation (Figure 4, Table 1). Inactivation of RAD54 (a gene encoding a key component of homologous recombination) or FANCD2 (a gene responsible for Fanconi anemia, FA) reduces gene conversion without increasing hypermutation [44,45] (Figure 4, Table 1). These pathways might contribute to gene conversion after strand exchange, when the commitment towards Ig gene conversion has been made.

Ig gene conversion is initiated at the AID-mediated lesion (Figure 4, Table 1). HR mediates a template switch to a homeologous upstream $\operatorname{IgV}$ pseudogene. HR is also accompanied by DNA synthesis, which is facilitated by TLS-polymerases, as evidenced by the following observations. Poln-deficient $\left(\mathrm{POL}^{-/-}\right)$cells show a reduced gene conversion rate with increased length of gene conversion tract in comparison with wild type cells [46] (Table 1). A role for Pol $\eta$ in D-loop extensions during HR reactions in vitro has been reported [47-50]. These data indicate involvement of Pol $\eta$ in Ig gene conversion and further imply that some backup polymerase(s) carrying higher processivity might compensate for the absence of Poln in $P O L \eta^{-/-}$cells. Such backup polymerases might be Polv and Pol $\theta$, since Ig gene conversion is completely abolished in $P O L \eta^{-/-} / \mathrm{POLv}^{-/-} / \mathrm{POL}^{-/-}$ cells [17] (Figure 4, Table 1). Thus, these TLS polymerases play roles not only in TLS but also in 
HR-mediated Ig gene conversion. The recruitment of TLS polymerases is promoted by ubiquitination of the proliferating cell nuclear antigen (PCNA) [51-53]. However, the role of PCNA ubiquitination in vertebrate $\mathrm{HR}$ and $\operatorname{Ig} V$ diversification has not been fully elucidated.

\begin{tabular}{|c|c|c|c|c|c|}
\hline $\mathrm{PMC}$ & Positive & $\begin{array}{l}\text { Zero or } \\
\text { Not tested }\end{array}$ & & Negative & \\
\hline 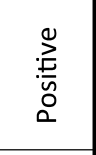 & & & $\begin{array}{l}\text { BRCA1 } \\
\text { BRCA2 } \\
\text { NBS1 } \\
\text { Pseudo V }\end{array}$ & $\begin{array}{l}\text { RAD9 } \\
\text { RAD17 } \\
\text { RAD51B } \\
\text { RAD51C }\end{array}$ & $\begin{array}{l}\text { RAD51D } \\
\text { UNG } \\
X R C C 2 \\
X R C C 3\end{array}$ \\
\hline 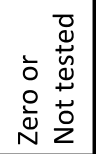 & $\begin{array}{l}\text { ASCIZ } \\
\text { HDAC2 } \\
\text { RECQL5 }\end{array}$ & $\begin{array}{ll}\text { DNA-PKCS } & \text { POLZ } \\
\text { KU70 } & \text { RAD52 } \\
\text { MSH6 } & \text { SHPRH } \\
\text { PMS2 } & \end{array}$ & $\begin{array}{l}\text { BLM } \\
\text { CTNNBL1 } \\
\text { E2A } \\
\text { FANCC }\end{array}$ & $\begin{array}{l}\text { FANCJ } \\
\text { FEN1 } \\
\text { POLN } \\
\text { POLQ }\end{array}$ & $\begin{array}{l}\text { RAD54 } \\
\text { RNF168 }\end{array}$ \\
\hline 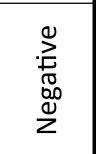 & POLD3 & $\begin{array}{l}\text { MMS2 } \\
\text { PCNA } \\
\text { RAD18 } \\
\text { REV1 }\end{array}$ & $\begin{array}{l}A I D \\
B A C H 2 \\
D D X 11 \\
\text { FANCD2 }\end{array}$ & $\begin{array}{l}\text { HERC2 } \\
\text { PARP-1 } \\
\text { POLH } \\
\text { RNF8 }\end{array}$ & SPRTN \\
\hline
\end{tabular}

Figure 4. Genes involved in Ig gene conversion and hypermutation. GC and PM represent gene conversion and hypermutation, respectively. Positive, zero or negative effects by gene deletion or mutation on gene conversion and hypermutation were categorized.

The heterotrimeric checkpoint clamp, consisting of the Rad9, Hus1, and Rad1 subunits (hereafter referred to as 9-1-1), is structurally similar to PCNA and serves as a DNA damage sensor to mediate the ATR signal axis [54-56]. The 9-1-1 clamp is loaded onto DNA by Rad17-RFC (replication factor C) in vitro, which is analogous to the PCNA-RFC clamp loader system [57,58]. In vertebrates, Rad9 and Rad17 play significant roles in HR as previously described [59,60]. RAD9 ${ }^{-/-}$and $R A D 17^{/-} \mathrm{DT} 40$ cells show strongly reduced Ig gene conversion and increased hypermutation [38] (Figure 4, Table 1). Considering limited effects on HR-mediated gene-targeting and DSB repair in comparison with severe defects in Ig gene conversion by the loss of Rad9 or Rad17, the role of these factors might be confined to a subset of the HR reaction initiated by replication fork stalling and associated with formation of single strand DNA (ssDNA) gaps, rather than induced by DSBs.

Recently, mutations in the XPD family helicase gene DDX11 were identified in the hereditary disorder Warsaw Breakage Syndrome (WABS) [61-64]. Cells from WABS patients have a shared feature with Fanconi anemia (FA) with respect to the hypersensitivity to interstrand-crosslink (ICL) inducing agents and increased chromosome aberrations, but to date DDX11 has not been formally classified as an FA gene [61-64]. A recent study revealed that DDX11 plays a critical backup role for the FA pathway regarding ICL repair in DT40 cells [65]. In addition to its role in ICL repair, DDX11 acts jointly with the 9-1-1 clamp to promote HR induced by various lesions. DDX11-/- DT40 cells are epistatic with $R A D 17^{/-}$with regards to DNA damage hypersensitivity and induction of sister-chromatid exchanges and chromosome aberrations [65]. Interestingly, DDX11-/- DT40 cells show reduced Ig gene conversion and hypermutation, with the effect of DDX11 in hypermutation being clearly observed in a rad17 defective background [65] (Figure 4, Table 1). Thus, DDX11 may be involved in the promotion of both HR and TLS for releasing stalled replication forks at lesions, with its function in these two modes possibly being regulated by 9-1-1 and its loader, Rad17. This dual role of DDX11 in affecting both gene conversion and hypermutation is reminiscent of other FA genes [66] known to integrate HR and TLS machineries to promote ICL repair. However, the interplay between the FA pathway as delineated so far, and DDX11 at abasic sites, remains to be elucidated by future studies.

SPARTAN, a ubiquitin-PCNA-interacting regulator, plays a complex role in regulating mutagenesis and in mediating repair of DNA-protein crosslink lesions. On one hand, SPARTAN promotes TLS by recruiting Poln to DNA lesions, which involves its association with ubiquitinated PCNA via its PCNA interacting peptide (PIP) domain and ubiquitin-binding zinc-finger 4 (UBZ4) 
domain [67-71]. On the other hand, SPARTAN recruits the p97 protein segregase and removes Poln from DNA damage sites, thereby preventing mutations [72,73]. In addition to its function as a ubiquitinated PCNA-binding TLS regulator, SPARTAN also mediates the repair of DNA-protein crosslink lesions through its DNA-dependent metalloprotease activity [74-77]. Thus, the role of SPARTAN at the stalled replication fork has been a matter of debate and remains controversial. Recent analysis using DT40 cells revealed that SPARTAN promotes not only TLS-mediated Ig hypermutation, but also Ig gene conversion [78] (Figure 4, Table 1). For promotion of Ig gene conversion, UBZ4 and not the PIP domain of SPARTAN is required, suggesting that SPARTAN recognizes ubiquitinated protein(s) other than PCNA to promote gene conversion [78]. Important questions for future studies concern the mechanisms underlying SPARTAN's role in the promotion of Ig gene conversion.

Moreover, as a general remark applied to most of the studies using AID overexpression to study $\operatorname{IgV}$ gene diversification, the factors under study may affect AID activity itself, a possibility that has not been formally ruled out. Recent work from the Sale Lab (Cambridge, UK) has used an ingenuous strategy to address this issue, by co-overexpressing together with AID a bacterial uracil glycosylase inhibitor and looking at whether the mutation rates induced by $\mathrm{dU}$ are similar to the ones observed in control cells [22]. Likely, this strategy will be applied in the future to the study of other factors and this will increase the knowledge of the mechanisms mediating AID regulation and $\operatorname{Ig} V$ diversification via bypass of abasic sites.

\section{Nontemplated Somatic Hypermutation}

Bypass replication by error-prone TLS polymerases causes hypermutation after the action of AID and UNG. Studies in budding yeast have revealed that mono-ubiquitination of PCNA at lysine 164 serves as a signal for the recruitment of error-prone TLS polymerases to sites of perturbed replication $[79,80]$. The role of PCNA ubiquitination was examined in $\psi V^{-}$DT40 cells, in which upstream $\operatorname{IgV}$ pseudogenes are completely eliminated and gene conversion events are diminished [27] (Figure 4, Table 1). The PCNA-K164R DT40 cells show impaired PCNA ubiquitination and exhibit hypersensitivity to a wide variety of DNA damaging agents. Moreover, Ig hypermutation is critically reduced in PCNA-K164R DT40 cells (Figure 4, Table 1), indicating that post-translational modification of PCNA at lysine 164 is required for efficient TLS events in $I g V$ gene diversification. Rad18, an E3-ligase required for PCNA ubiquitination in yeast, is conserved in eukaryotic cells $[79,81]$. RAD18 ${ }^{-/-}$DT40 cells exhibit a milder reduction in cellular tolerance to DNA damaging agents and Ig hypermutation in comparison to PCNA-K164R cells (Figure 4, Table 1), and this mutant strain showed residual PCNA ubiquitination [27,82]. Moreover, RAD18 ${ }^{-/-} / P C N A-K 164 R$ double mutant cells essentially show the same phenotype as PCNA-K164R mutant cells [27]. These observations suggest that Rad18-mediated PCNA ubiquitination is required for TLS events, but other ubiquitin ligases seem to function as a backup for Rad18 in vertebrate cells. The mutation spectrum in PCNA-K164R DT40 cells is changed, and this cell line shows biased reduction of dG:dC to dC:dG transversion [27]. Similarly, the loss of Rev1 results in nearly complete loss of the $\mathrm{dG}: \mathrm{dC}$ to $\mathrm{dC}: \mathrm{dG}$ transversion mutation [27] (Figure 4, Table 1). Ig hypermutation requires the deoxycytidyl transferase activity of Rev1 that is dispensable for cellular tolerance to DNA damaging agents, suggesting that the transferase activity of Rev1 incorporates $\mathrm{dC}$ opposite to the abasic site [41]. More importantly, other types of $\operatorname{IgV}$ hypermutations are also significantly reduced in PCNA-K164R cells, but not in $R E V 1^{-/-}$cells, suggesting that PCNA ubiquitination activates other TLS polymerases apart from Rev1.

$P O L \eta^{-1-} / P_{O L L}{ }^{-/-}$DT40 cells also show reduced dG:dC to $\mathrm{dC}: \mathrm{dG}$ mutations and increased $\mathrm{dG}: \mathrm{dC}$ to $\mathrm{dA}: \mathrm{dT}$ mutations. Moreover, this cell line has a wild type level of Ig hypermutations [14]. These observations suggest that the absence of Pol $\eta$ and $\mathrm{Pol} \zeta$ is largely compensated by the action of other polymerase(s) possessing activity to preferentially incorporate $\mathrm{dA}$ opposite the abasic site. Interestingly, $\mathrm{POL}^{-/}{ }^{-}$DT40 cells have pronounced defects in TLS across T-T (6-4) UV photoproducts, while loss of Poln critically restores this defect. Similarly, $P O L \eta^{-1-} / P O L \zeta^{-/-}$DT40 cells exhibit milder DNA damage sensitivity in comparison to $P O L \zeta^{-/-}$cells [14]. These observations suggest 
that actions of Poln in the absence of Pol $\zeta$ critically impair the functionality of TLS. The absence of

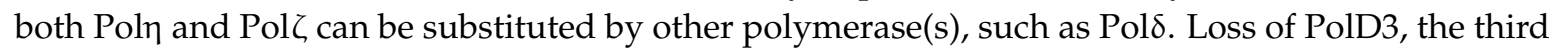
subunit of the Pol $\delta$ holoenzyme, results in a five-fold reduction of Ig hypermutation efficiency [16], suggesting a possible role of Pol $\delta$ in TLS across abasic sites (Figure 4, Table 1). This view is supported

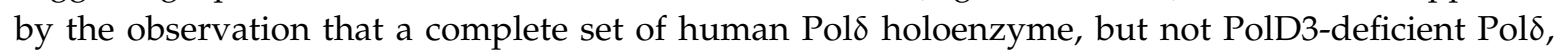
efficiently replicates across abasic sites in vitro [16]. Moreover, inactivation of the proofreading exonuclease activity dramatically enhances TLS across abasic sites in vitro [15], suggesting that this activity counteracts bypass replication presumably due to excision of incorporated nucleotides at damaged templates. Strikingly, the expression of proofreading exonuclease activity-deficient Pol $\delta$ by introducing a heteroallelic point mutation $\left(P O L D 1^{+/ e x o-}\right)$ rescues the mutant phenotype of $P O L D 3^{-/-}$ cells, and the Ig hypermutation in $P O L D 3^{-/-} / P O L D 1^{+/ e x o-}$ returns to wild type levels [15]. These observations suggest that PolD3 counteracts Pol $\delta$ 's proofreading exonuclease activity in order to promote TLS across abasic sites during $\operatorname{Ig} V$ gene diversification, and support a pivotal role of PolD3 in Pol $\delta$-mediated TLS. The loss of PolD3 in POL $\eta^{-/-} / P O L \zeta^{-/-}$DT40 cells results in synthetic lethality, and this lethality is partially suppressed by the expression of proofreading exonuclease activity-deficient Pol $\delta$ [15]. Thus, TLS relying on Pol $\eta-\mathrm{Pol} \zeta$ and Pol $\delta$ might participate in parallel pathways promoting cell survival.

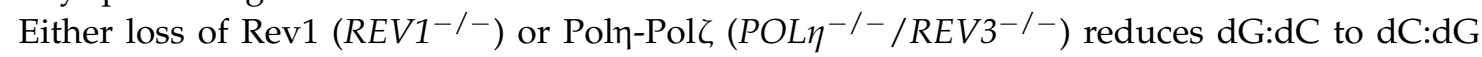
transversions [14,27]. This might be attributable to the loss of Pol $\zeta$ activity in these mutant cells, as evidenced by the following observations. DT40 REV1 ${ }^{-/-} R E V 3^{-/-} R E V 7^{-/-}$triple mutant cells show hypersensitivity to genotoxic agents as observed in each single mutant cell, indicating an epistatic relationship between these factors [83]. These observations further suggest that Rev1, Rev3 and Rev7 function cooperatively in the TLS pathway as Pol $\zeta$.

Other TLS polymerases, including Polv and Pol $\theta$, might also be involved in Ig hypermutation, since inactivation of Polv and PolO in POL $\eta^{-/-}$cells significantly reduced Ig hypermutation [17] (Figure 4, Table 1). However, to fully understand the redundancy as well as the division of labor among polymerases in the TLS network further investigations are needed.

The spatiotemporal regulation of the repair of AID-induced abasic sites, that is, whether the repair/bypass of these sites happens at the level of the fork, or behind the fork, remains an issue of investigation. So far, indirect assays have been used to assess the involvement of a subset of the factors implicated in this process in regulating fork speed and gap-filling. Specifically, DNA fiber assays following UV or MMS (methylmethane sulfonate) damage can measure damage bypass events at the fork, whereas alkaline sucrose gradient sedimentation of pulse labeled cells show the efficiency of post-replicative processes [84]. For instance, $P O L \eta^{-/-} P O L \zeta^{-/-}$mutants show only defects in the post-replicative gap-filling assay, whereas $P O L D 3^{-/-}$mutants show defects only in the fork speed assay $[15,16]$. Thus, although these assays do not probe for events at the $\operatorname{Ig} V$ locus or in conditions with increased abasic sites, these data suggest that $\operatorname{Ig} V$ diversification may happen both at the fork and in the $\mathrm{G} 2$ phase, and may be mediated by distinct factors.

\section{Summary and Perspective}

In this review, we summarized the current understanding of mechanisms promoting recovery of arrested replication forks at damaged DNA templates as unveiled by the analysis of $\operatorname{Ig} V$ gene diversification in avian DT40 cells. This cell line exhibits extraordinarily high gene-targeting efficiency and has thus been extensively used for genetic studies [33]. Moreover, this cell line provides a great opportunity to analyze gene functions in replication fork recovery and/or gap-filling at damaged templates by analyzing $\operatorname{Ig} V$ gene diversification. Thus, genetic studies using the DT40 cell line might continue to contribute to the understanding of DDT mechanisms in eukaryotic cells. The genes involved in $\operatorname{IgV}$ gene diversification (gene conversion and hypermutation) are summarized in Table 1.

Genetic studies of yeast have greatly contributed to the understanding of mechanisms regulating TLS and HR-mediated template switch to recover arrested forks at damaged DNA templates [79,85-89]. 
The mono-ubiquitination on PCNA at lysine 164 by Rad6 (E2 conjugating enzyme) and Rad18 (E3 ligase) serves as a signal for promoting TLS [87], while extension of this ubiquitin to a polyubiquitin chain by Ubc13 (E2 conjugating enzyme) and Rad5 (E3 ligase) facilitates template switch [85,89]. Studies in the mouse model using PCNA-K164R or RAD18 ${ }^{-/-}$mutant cells demonstrated an important role of PCNA ubiquitination in the maintenance of hematopoeotic stem cells, avoidance of premature aging and DNA damage tolerance, highlighting the critical role of this pathway for genome maintenance in mammals $[90,91]$. Studies using DT40 cells also revealed conserved mechanisms of the Rad18-PCNA ubiquitination axis in TLS promotion and suggested the role of additional E3 ubiquitin ligases in this ubiquitination process [27,82]. In addition to promoting TLS, Rad18 functions in concert with another E3 ligase, Rnf8, and plays a significant role in HR promotion in DT40 cells [12], as it does in budding yeast [89]. The role of Rad18 in the promotion of HR in vertebrate cells occurs via a direct interaction with the RAD51 paralog Rad51C [92]. Thus, the roles of Rad18 and the mechanisms of PCNA mono-ubiquitination might be considerably more complex in higher eukaryotic cells in comparison to yeast cells. SHPRH and HLTF are identified human homologs of Rad5 [93-96], and depletion of these E3 ligases resulted in reduction of PCNA poly-ubiquitination and rendered cells hypersensitive to DNA damaging agents $[93,94]$. These observations highlighted the importance of PCNA poly-ubiquitination via Rad5 homologs in human cells. However, SHPRH ${ }^{-/-}$DT40 cells showed no detectable defects in the ubiquitination of PCNA or cellular tolerance to alkylating agents and Ig diversification (Figure 4, Table 1), but they did show higher sensitivity to the topoisomerase II inhibitor, etoposide, in comparison to wild type cells [97]. Moreover, HLTF is missing in the chicken genome [97]. The redundancy of E3 ligases in PCNA ubiquitination might be linked to different roles of this modification in genome maintenance and genetic plasticity. Moreover, in human cells, Ubc13 (an E2 conjugating enzyme) plays a role in DSB repair. Rnf8 (E3 ligase), in complex with Ubc13, ubiquitinates histone H2A surrounding DSB sites [98,99], and then the Rnf168 (E3 ligase)-Ubc13 complex further amplifies histone ubiquitination [100] to recruit downstream repair factors, including BRCA1, that are required for the recruitment of Rad51 to DSB sites [101,102]. Similarly, UBC13-/DT40 cells show defective DSB repair due to impaired Rad51 recruitment [103]. Furthermore, Rnf8 (E3 ligase) also contributes to both Ig hypermutation and gene conversion in DT40 cells [104] (Figure 4, Table 1). Taken together, these observations suggest that the Ubc13-Rad5 axis unveiled in yeast studies cannot be directly extrapolated into higher eukaryotic cells, due to considerable redundancy in ubiquitination enzyme networks and differential functions of the key enzymes. Moreover, the role of PCNA in HR-mediated template switch has not been elucidated. Comprehensive analysis of the ubiquitination pathway is warranted to fully dissect the molecular mechanisms of the ubiquitination signal pathway in DNA damage responses. 
Table 1. Genes involved in Ig gene conversion and hypermutation.

\begin{tabular}{|c|c|c|c|c|}
\hline Gene Name & GC & PM & Method & Reference \\
\hline$A I D$ & - & - & IgM gain and sequencing & Arakawa et al., 2002 [105] \\
\hline ASCIZ & + & 0 & IgM gain, $\mathrm{mAID}$ overexpression and sequencing & Oka et al., 2008 [106] \\
\hline BACH2 & - & - & IgM gain and sequencing & Budzynska et al., 2017 [107] \\
\hline$B L M$ & - & NT & IgM gain & Kikuchi et al., 2009 [108] \\
\hline BRCA1 & - & + & IgM loss and sequencing & Longerich et al., 2008 [42] \\
\hline$B R C A 2$ & - & + & IgM loss and sequencing & Hatanaka et al., 2005 [43] \\
\hline CTNNBL1 & - & NT & IgM gain & Conticello et al., 2008 [109] \\
\hline DDX11 & - & - & IgM gain, mAID overexpression and sequencing & Abe et al., 2018 [65] \\
\hline$D N A-P K C S$ & NT & 0 & IgM loss & Sale et al., 2001 [40] \\
\hline$E 2 A$ & - & 0 & IgM gain and sequencing & Kitao et al., 2008 [110] \\
\hline FANCC & - & NT & IgM loss and sequencing & Pace et al., 2010 [111] \\
\hline FANCD2 & - & - & IgM loss, gain and sequencing & Yamamoto et al., 2005 [45] \\
\hline FANCJ & - & NT & IgM loss and sequencing & Kitao et al., 2011 [112] \\
\hline FEN1 & - & NT & IgM gain and sequencing & Kikuchi et al., 2005 [113] \\
\hline HDAC2 & + & 0 & IgM gain and sequencing & Lin et al., 2008 [114] \\
\hline HERC2 & - & - & mAID overexpression and sequencing & Mohiuddin et al., 2016 [104] \\
\hline KU70 & NT & 0 & IgM loss & Sale et al., 2001 [40] \\
\hline MMS2 & 0 & - & IgM loss and sequencing & Simpson et al., 2005 [115] \\
\hline MSH6 & 0 & 0 & IgM gain and sequencing & Campo et al., 2013 [116] \\
\hline NBS1 $(p 70)$ & - & + & sIgM gain, mAID overexpression and sequencing & Nakahara et al., 2009 [117] \\
\hline PARP-1 & - & - & IgM gain, mAID overexpression and sequencing & Paddock et al., 2010 [118] \\
\hline PCNA (K164R) & NT & - & IgM loss and sequencing & Arakawa et al., $2006[27]$ \\
\hline PMS2 & 0 & 0 & IgM gain and sequencing & Campo et al., 2013 [116] \\
\hline POLD3 & + & - & mAID overexpression and sequencing & Hirota et al., 2015 [16] \\
\hline POLH & - & - & IgM gain and sequencing & Kawamoto et al., 2006 [46], Kohzaki et al., 2010 [17] \\
\hline POLN & - & 0 & IgM gain, mAID overexpression and sequencing & Kohzaki et al., 2010 [17] \\
\hline POLQ & - & 0 & IgM gain, $\mathrm{mAID}$ overexpression and sequencing & Kohzaki et al., 2010 [17] \\
\hline POLH/POLN/POLQ & - & - & IgM gain, mAID overexpression and sequencing & Kohzaki et al., 2010 [17] \\
\hline POLZ (REV3) & 0 & NT & IgM gain and sequencing & Okada et al., 2005 [83] \\
\hline Pseudo $V$ & - & + & IgM loss and sequencing & Arakawa et al., 2004 [28] \\
\hline RAD9 & - & + & mAID overexpression and sequencing & Saberi et al., 2008 [38] \\
\hline RAD17 & - & + & mAID overexpression and sequencing & Saberi et al., 2008 [38] \\
\hline RAD18 & NT & - & IgM loss and sequencing & Arakawa et al., 2006 [27] \\
\hline$R A D 51 B$ & - & + & IgM loss and sequencing & Sale et al., 2001 [40] \\
\hline
\end{tabular}


Table 1. Cont.

\begin{tabular}{lllll}
\hline Gene Name & GC & PM & Method & Reference \\
\hline RAD51C & - & + & IgM loss and sequencing & Hatanaka et al., 2005 [43] \\
RAD51D & - & + & IgM loss and sequencing & Hatanaka et al., 2005 [43] \\
RAD52 & NT & 0 & IgM loss & Sale et al., 2001 [40] \\
RAD54 & - & $\mathrm{NT}$ & IgM gain and sequencing & Bezzubova et al., 1997 [44] \\
RECQL5 & + & $\mathrm{NT}$ & IgM gain and sequencing & Hosono et al., 2014 [119] \\
RNF8 & - & - & mAID overexpression and sequencing & Mohiuddin et al., 2016 [104] \\
RNF168 & - & 0 & mAID overexpression and sequencing & Mohiuddin et al., 2016 [104] \\
SPRTN & - & - & IgM gain, mAID overexpression and sequencing & Nakazato et al., 2018 [78] \\
SHPRH & 0 & 0 & sIgM gain and sequencing & Tomi et al., 2014 [97] \\
REV1 & 0 & - & IgM loss and sequencing & Simpson et al., 2003 [120] \\
UNG & - & + & IgM gain, loss and sequencing & Saribasak et al., 2005 [25] \\
XRCC2 & - & + & IgM loss and sequencing & Sale et al., 2001 [40] \\
XRCC3 & - & + & IgM loss and sequencing & Sale et al., 2001 [40] \\
GC and PM represent gene conversion and hypermutation, respectively. Positive, zero and negative effects by gene deletion or mutation are shown by,+ 0 and,- respectively. NT:
\end{tabular}

not tested. 
Funding: This work was supported by the Network-type Joint Usage/Research Center for Radiation Disaster Medical Science of Hiroshima University, Nagasaki University, and Fukushima Medical University. This work was funded by JSPS KAKENHI (JP16K12598, JP 16H01314 and 16H02957), the Yamada Science Foundation, and the Takeda Science Foundation to K.H.; and the AIRC IG grant18976 to D.B.

Conflicts of Interest: The authors declare no conflicts of interest.

\section{References}

1. McCulloch, S.D.; Kunkel, T.A. The fidelity of DNA synthesis by eukaryotic replicative and translesion synthesis polymerases. Cell Res. 2008, 18, 148-161. [CrossRef] [PubMed]

2. Schmitt, M.W.; Matsumoto, Y.; Loeb, L.A. High fidelity and lesion bypass capability of human DNA polymerase delta. Biochimie 2009, 91, 1163-1172. [CrossRef] [PubMed]

3. Branzei, D.; Foiani, M. Regulation of DNA repair throughout the cell cycle. Nat. Rev. Mol. Cell Biol. 2008, 9 , 297-308. [CrossRef] [PubMed]

4. Lindahl, T. Instability and decay of the primary structure of DNA. Nature 1993, 362, 709-715. [CrossRef] [PubMed]

5. Friedberg, E.C.; Walker, G.C.; Siede, W.; Wood, R.D.; Schultz, R.A.; Ellenberger, T. DNA Repair and Mutagenesis; ASM Press: Boston, MA, USA, 2006.

6. Barnes, D.E.; Lindahl, T.; Sedgwick, B. DNA repair. Curr. Opin. Cell Biol. 1993, 5, 424-433. [CrossRef]

7. Klungland, A.; Rosewell, I.; Hollenbach, S.; Larsen, E.; Daly, G.; Epe, B.; Seeberg, E.; Lindahl, T.; Barnes, D.E. Accumulation of premutagenic DNA lesions in mice defective in removal of oxidative base damage. Proc. Natl. Acad. Sci. USA 1999, 96, 13300-13305. [CrossRef] [PubMed]

8. Loeb, L.A. Apurinic sites as mutagenic intermediates. Cell 1985, 40, 483-484. [CrossRef]

9. Prasad, R.; Horton, J.K.; Liu, Y.; Wilson, S.H. Central steps in mammalian BER and regulation by PARP1. Base Excision Repair Pathw. 2017, 253-280. [CrossRef]

10. Branzei, D.; Psakhye, I. DNA damage tolerance. Curr. Opin. Cell Biol. 2016, 40, 137-144. [CrossRef] [PubMed]

11. Gao, Y.; Mutter-Rottmayer, E.; Zlatanou, A.; Vaziri, C.; Yang, Y. Mechanisms of post-replication DNA repair. Genes 2017, 8, 64. [CrossRef] [PubMed]

12. Kobayashi, S.; Kasaishi, Y.; Nakada, S.; Takagi, T.; Era, S.; Motegi, A.; Chiu, R.K.; Takeda, S.; Hirota, K. Rad18 and Rnf8 facilitate homologous recombination by two distinct mechanisms, promoting Rad51 focus formation and suppressing the toxic effect of nonhomologous end joining. Oncogene 2015, 34, 4403-4411. [CrossRef] [PubMed]

13. Li, X.; Heyer, W.D. Homologous recombination in DNA repair and DNA damage tolerance. Cell Res. 2008, 18, 99-113. [CrossRef] [PubMed]

14. Hirota, K.; Sonoda, E.; Kawamoto, T.; Motegi, A.; Masutani, C.; Hanaoka, F.; Szuts, D.; Iwai, S.; Sale, J.E.; Lehmann, A.; et al. Simultaneous disruption of two DNA polymerases, Poleta and Polzeta, in Avian DT40 cells unmasks the role of Poleta in cellular response to various DNA lesions. PLoS Genet. 2010, 6, e1001151. [CrossRef] [PubMed]

15. Hirota, K.; Tsuda, M.; Tsurimoto, T.; Cohen, I.S.; Livneh, Z.; Kobayashi, K.; Narita, T.; Nishihara, K.; Murai, J.; Iwai, S.; et al. In vivo evidence for translesion synthesis by the replicative DNA polymerase delta. Nucleic Acids Res. 2016, 44, 7242-7250. [CrossRef] [PubMed]

16. Hirota, K.; Yoshikiyo, K.; Guilbaud, G.; Tsurimoto, T.; Murai, J.; Tsuda, M.; Phillips, L.G.; Narita, T.; Nishihara, K.; Kobayashi, K.; et al. The POLD3 subunit of DNA polymerase $\delta$ can promote translesion synthesis independently of DNA polymerase $\zeta$. Nucleic Acids Res. 2015, 43, 1671-1683. [CrossRef] [PubMed]

17. Kohzaki, M.; Nishihara, K.; Hirota, K.; Sonoda, E.; Yoshimura, M.; Ekino, S.; Butler, J.E.; Watanabe, M.; Halazonetis, T.D.; Takeda, S. DNA polymerases $v$ and $\theta$ are required for efficient immunoglobulin V gene diversification in chicken. J. Cell Biol. 2010, 189, 1117-1127. [CrossRef]

18. Sale, J.E. Competition, collaboration and coordination-determining how cells bypass DNA damage. J. Cell Sci. 2012, 125, 1633-1643. [CrossRef]

19. Arakawa, H.; Buerstedde, J.M. Activation-induced cytidine deaminase-mediated hypermutation in the DT40 cell line. Philos. Trans. R. Soc. Lond. B Biol. Sci. 2009, 364, 639-644. [CrossRef]

20. Sale, J.E. Translesion DNA synthesis and mutagenesis in eukaryotes. Cold Spring Harb. Perspect. Biol. 2013, 5, a012708. [CrossRef] 
21. Sale, J.E.; Batters, C.; Edmunds, C.E.; Phillips, L.G.; Simpson, L.J.; Szuts, D. Timing matters: Error-prone gap filling and translesion synthesis in immunoglobulin gene hypermutation. Philos. Trans. R. Soc. Lond. B Biol. Sci. 2009, 364, 595-603. [CrossRef]

22. Romanello, M.; Schiavone, D.; Frey, A.; Sale, J.E. Histone H3.3 promotes $I g V$ gene diversification by enhancing formation of AID-accessible single-stranded DNA. EMBO J. 2016, 35, 1452-1464. [CrossRef] [PubMed]

23. Jin, C.; Felsenfeld, G. Nucleosome stability mediated by histone variants H3.3 and H2A.Z. Genes Dev. 2007, 21, 1519-1529. [CrossRef] [PubMed]

24. Di Noia, J.; Neuberger, M.S. Altering the pathway of immunoglobulin hypermutation by inhibiting uracil-DNA glycosylase. Nature 2002, 419, 43-48. [CrossRef]

25. Saribasak, H.; Saribasak, N.N.; Ipek, F.M.; Ellwart, J.W.; Arakawa, H.; Buerstedde, J.M. Uracil DNA glycosylase disruption blocks Ig gene conversion and induces transition mutations. J. Immunol. 2006, 176, 365-371. [CrossRef] [PubMed]

26. Blagodatski, A.; Batrak, V.; Schmidl, S.; Schoetz, U.; Caldwell, R.B.; Arakawa, H.; Buerstedde, J.M. A cis-acting diversification activator both necessary and sufficient for AID-mediated hypermutation. PLoS Genet. 2009, 5, e1000332. [CrossRef]

27. Arakawa, H.; Moldovan, G.L.; Saribasak, H.; Saribasak, N.N.; Jentsch, S.; Buerstedde, J.M. A role for PCNA ubiquitination in immunoglobulin hypermutation. PLoS Biol. 2006, 4, e366. [CrossRef]

28. Arakawa, H.; Saribasak, H.; Buerstedde, J.M. Activation-induced cytidine deaminase initiates immunoglobulin gene conversion and hypermutation by a common intermediate. PLoS Biol. 2004, 2, e179. [CrossRef]

29. Di Noia, J.M.; Neuberger, M.S. Molecular mechanisms of antibody somatic hypermutation. Annu. Rev. Biochem. 2007, 76, 1-22. [CrossRef]

30. Sale, J.E. Immunoglobulin diversification in DT40: A model for vertebrate DNA damage tolerance. DNA Repair 2004, 3, 693-702. [CrossRef]

31. Sale, J.E. Measurement of diversification in the immunoglobulin light chain gene of DT40 cells. Methods Mol. Biol. 2012, 920, 417-432. [CrossRef]

32. Buerstedde, J.M.; Reynaud, C.A.; Humphries, E.H.; Olson, W.; Ewert, D.L.; Weill, J.C. Light chain gene conversion continues at high rate in an ALV-induced cell line. EMBO J. 1990, 9, 921-927. [CrossRef] [PubMed]

33. Buerstedde, J.M.; Takeda, S. Increased ratio of targeted to random integration after transfection of chicken B cell lines. Cell 1991, 67, 179-188. [CrossRef]

34. Seo, H.; Masuoka, M.; Murofushi, H.; Takeda, S.; Shibata, T.; Ohta, K. Rapid generation of specific antibodies by enhanced homologous recombination. Nat. Biotechnol. 2005, 23, 731-735. [CrossRef]

35. Cummings, W.J.; Yabuki, M.; Ordinario, E.C.; Bednarski, D.W.; Quay, S.; Maizels, N. Chromatin structure regulates gene conversion. PLoS Biol. 2007, 5, e246. [CrossRef]

36. Arakawa, H. Immunoglobulin gene conversion and hypermutation assay by FACs. Sub-Cell. Biochem. 2006, 40, 351-352.

37. Shinkura, R.; Ito, S.; Begum, N.A.; Nagaoka, H.; Muramatsu, M.; Kinoshita, K.; Sakakibara, Y.; Hijikata, H.; Honjo, T. Separate domains of AID are required for somatic hypermutation and class-switch recombination. Nat. Immunol. 2004, 5, 707-712. [CrossRef] [PubMed]

38. Saberi, A.; Nakahara, M.; Sale, J.E.; Kikuchi, K.; Arakawa, H.; Buerstedde, J.M.; Yamamoto, K.; Takeda, S.; Sonoda, E. The 9-1-1 DNA clamp is required for immunoglobulin gene conversion. Mol. Cell. Biol. 2008, 28, 6113-6122. [CrossRef] [PubMed]

39. Wang, M.; Yang, Z.; Rada, C.; Neuberger, M.S. AID upmutants isolated using a high-throughput screen highlight the immunity/cancer balance limiting DNA deaminase activity. Nat. Struct. Mol. Biol. 2009, 16, 769-776. [CrossRef] [PubMed]

40. Sale, J.E.; Calandrini, D.M.; Takata, M.; Takeda, S.; Neuberger, M.S. Ablation of XRCC2/3 transforms immunoglobulin V gene conversion into somatic hypermutation. Nature 2001, 412, 921-926. [CrossRef] [PubMed]

41. Ross, A.L.; Sale, J.E. The catalytic activity of REV1 is employed during immunoglobulin gene diversification in DT40. Mol. Immunol. 2006, 43, 1587-1594. [CrossRef] [PubMed]

42. Longerich, S.; Orelli, B.J.; Martin, R.W.; Bishop, D.K.; Storb, U. Brca1 in immunoglobulin gene conversion and somatic hypermutation. DNA Repair 2008, 7, 253-266. [CrossRef] [PubMed] 
43. Hatanaka, A.; Yamazoe, M.; Sale, J.E.; Takata, M.; Yamamoto, K.; Kitao, H.; Sonoda, E.; Kikuchi, K.; Yonetani, Y.; Takeda, S. Similar effects of Brca2 truncation and Rad51 paralog deficiency on immunoglobulin $\mathrm{V}$ gene diversification in DT40 cells support an early role for Rad51 paralogs in homologous recombination. Mol. Cell. Biol. 2005, 25, 1124-1134. [CrossRef] [PubMed]

44. Bezzubova, O.; Silbergleit, A.; Yamaguchi-Iwai, Y.; Takeda, S.; Buerstedde, J.M. Reduced X-ray resistance and homologous recombination frequencies in a RAD54-/- mutant of the chicken DT40 cell line. Cell 1997, 89, 185-193. [CrossRef]

45. Yamamoto, K.; Hirano, S.; Ishiai, M.; Morishima, K.; Kitao, H.; Namikoshi, K.; Kimura, M.; Matsushita, N.; Arakawa, H.; Buerstedde, J.M.; et al. Fanconi anemia protein FANCD2 promotes immunoglobulin gene conversion and DNA repair through a mechanism related to homologous recombination. Mol. Cell. Biol. 2005, 25, 34-43. [CrossRef] [PubMed]

46. Kawamoto, T.; Araki, K.; Sonoda, E.; Yamashita, Y.M.; Harada, K.; Kikuchi, K.; Masutani, C.; Hanaoka, F.; Nozaki, K.; Hashimoto, N.; et al. Dual roles for DNA polymerase eta in homologous DNA recombination and translesion DNA synthesis. Mol. Cell 2005, 20, 793-799. [CrossRef] [PubMed]

47. Li, J.; Holzschu, D.L.; Sugiyama, T. PCNA is efficiently loaded on the DNA recombination intermediate to modulate polymerase $\delta, \eta$, and $\zeta$ activities. Proc. Natl. Acad. Sci. USA 2013, 110, 7672-7677. [CrossRef] [PubMed]

48. Mcllwraith, M.J.; Vaisman, A.; Liu, Y.; Fanning, E.; Woodgate, R.; West, S.C. Human DNA polymerase $\eta$ promotes DNA synthesis from strand invasion intermediates of homologous recombination. Mol. Cell 2005, 20, 783-792. [CrossRef] [PubMed]

49. Sebesta, M.; Burkovics, P.; Haracska, L.; Krejci, L. Reconstitution of DNA repair synthesis in vitro and the role of polymerase and helicase activities. DNA Repair 2011, 10, 567-576. [CrossRef] [PubMed]

50. Sebesta, M.; Burkovics, P.; Juhasz, S.; Zhang, S.; Szabo, J.E.; Lee, M.Y.; Haracska, L.; Krejci, L. Role of PCNA and TLS polymerases in D-loop extension during homologous recombination in humans. DNA Repair 2013, 12, 691-698. [CrossRef] [PubMed]

51. Kannouche, P.L.; Wing, J.; Lehmann, A.R. Interaction of human DNA polymerase $\eta$ with monoubiquitinated PCNA: A possible mechanism for the polymerase switch in response to DNA damage. Mol. Cell 2004, 14, 491-500. [CrossRef]

52. Moldovan, G.L.; Pfander, B.; Jentsch, S. PCNA, the maestro of the replication fork. Cell 2007, 129, 665-679. [CrossRef] [PubMed]

53. Ulrich, H.D. Deubiquitinating PCNA: A downside to DNA damage tolerance. Nat. Cell Biol. 2006, 8, 303-305. [CrossRef] [PubMed]

54. Navadgi-Patil, V.M.; Burgers, P.M. The unstructured C-Terminal tail of the 9-1-1 clamp subunit Ddc1 activates Mec1/ATR via two distinct mechanisms. Mol. Cell 2009, 36, 743-753. [CrossRef] [PubMed]

55. Navadgi-Patil, V.M.; Burgers, P.M. A tale of two tails: Activation of DNA damage checkpoint kinase Mec1/ATR by the 9-1-1 clamp and by Dpb11/TopBP1. DNA Repair 2009, 8, 996-1003. [CrossRef]

56. Niida, H.; Nakanishi, M. DNA damage checkpoints in mammals. Mutagenesis 2006, 21, 3-9. [CrossRef]

57. Bermudez, V.P.; Lindsey-Boltz, L.A.; Cesare, A.J.; Maniwa, Y.; Griffith, J.D.; Hurwitz, J.; Sancar, A. Loading of the human 9-1-1 checkpoint complex onto DNA by the checkpoint clamp loader hRad17-replication factor C complex in vitro. Proc. Natl. Acad. Sci. USA 2003, 100, 1633-1638. [CrossRef]

58. Ellison, V.; Stillman, B. Biochemical characterization of DNA damage checkpoint complexes: Clamp loader and clamp complexes with specificity for 5' recessed DNA. PLoS Biol. 2003, 1, E33. [CrossRef]

59. Budzowska, M.; Jaspers, I.; Essers, J.; de Waard, H.; van Drunen, E.; Hanada, K.; Beverloo, B.; Hendriks, R.W.; de Klein, A.; Kanaar, R.; et al. Mutation of the mouse Rad17 gene leads to embryonic lethality and reveals a role in DNA damage-dependent recombination. EMBO J. 2004, 23, 3548-3558. [CrossRef]

60. Pandita, R.K.; Sharma, G.G.; Laszlo, A.; Hopkins, K.M.; Davey, S.; Chakhparonian, M.; Gupta, A.; Wellinger, R.J.; Zhang, J.; Powell, S.N.; et al. Mammalian Rad9 plays a role in telomere stability, S- and $\mathrm{G}_{2}$-phase-specific cell survival, and homologous recombinational repair. Mol. Cell. Biol. 2006, 26, 1850-1864. [CrossRef]

61. Bailey, C.; Fryer, A.E.; Greenslade, M. Warsaw Breakage Syndrome-A further report, emphasising cutaneous findings. Eur. J. Med. Genet. 2015, 58, 235-237. [CrossRef]

62. Capo-Chichi, J.M.; Bharti, S.K.; Sommers, J.A.; Yammine, T.; Chouery, E.; Patry, L.; Rouleau, G.A.; Samuels, M.E.; Hamdan, F.F.; Michaud, J.L.; et al. Identification and biochemical characterization of a novel mutation in DDX11 causing Warsaw breakage syndrome. Hum. Mutat. 2013, 34, 103-107. [CrossRef] [PubMed] 
63. Eppley, S.; Hopkin, R.J.; Mendelsohn, B.; Slavotinek, A.M. Clinical Report: Warsaw Breakage Syndrome with small radii and fibulae. Am. J. Med. Genet. A 2017, 173, 3075-3081. [CrossRef] [PubMed]

64. Van der Lelij, P.; Chrzanowska, K.H.; Godthelp, B.C.; Rooimans, M.A.; Oostra, A.B.; Stumm, M.; Zdzienicka, M.Z.; Joenje, H.; de Winter, J.P. Warsaw breakage syndrome, a cohesinopathy associated with mutations in the XPD helicase family member DDX11/ChIR1. Am. J. Hum. Genet. 2010, 86, 262-266. [CrossRef] [PubMed]

65. Abe, T.; Ooka, M.; Kawasumi, R.; Miyata, K.; Takata, M.; Hirota, K.; Branzei, D. Warsaw breakage syndrome DDX11 helicase acts jointly with RAD17 in the repair of bulky lesions and replication through abasic sites. Proc. Natl. Acad. Sci. USA 2018, 115, 8412-8417. [CrossRef] [PubMed]

66. Niedzwiedz, W.; Mosedale, G.; Johnson, M.; Ong, C.Y.; Pace, P.; Patel, K.J. The Fanconi anaemia gene FANCC promotes homologous recombination and error-prone DNA repair. Mol. Cell 2004, 15, 607-620. [CrossRef] [PubMed]

67. Centore, R.C.; Yazinski, S.A.; Tse, A.; Zou, L. Spartan/C1orf124, a reader of PCNA ubiquitylation and a regulator of UV-induced DNA damage response. Mol. Cell 2012, 46, 625-635. [CrossRef] [PubMed]

68. Ghosal, G.; Leung, J.W.; Nair, B.C.; Fong, K.W.; Chen, J. Proliferating cell nuclear antigen (PCNA)-binding protein C1orf124 is a regulator of translesion synthesis. J. Biol. Chem. 2012, 287, 34225-34233. [CrossRef]

69. Juhasz, S.; Balogh, D.; Hajdu, I.; Burkovics, P.; Villamil, M.A.; Zhuang, Z.; Haracska, L. Characterization of human Spartan/C1orf124, an ubiquitin-PCNA interacting regulator of DNA damage tolerance. Nucleic Acids Res. 2012, 40, 10795-10808. [CrossRef]

70. Machida, Y.; Kim, M.S.; Machida, Y.J. Spartan/C1orf124 is important to prevent UV-induced mutagenesis. Cell Cycle 2012, 11, 3395-3402. [CrossRef]

71. Toth, A.; Hegedus, L.; Juhasz, S.; Haracska, L.; Burkovics, P. The DNA-binding box of human SPARTAN contributes to the targeting of Poleta to DNA damage sites. DNA Repair 2017, 49, 33-42. [CrossRef]

72. Davis, E.J.; Lachaud, C.; Appleton, P.; Macartney, T.J.; Nathke, I.; Rouse, J. DVC1 (C1orf124) recruits the p97 protein segregase to sites of DNA damage. Nat. Struct. Mol. Biol. 2012, 19, 1093-1100. [CrossRef] [PubMed]

73. Mosbech, A.; Gibbs-Seymour, I.; Kagias, K.; Thorslund, T.; Beli, P.; Povlsen, L.; Nielsen, S.V.; Smedegaard, S.; Sedgwick, G.; Lukas, C.; et al. DVC1 (C1orf124) is a DNA damage-targeting p97 adaptor that promotes ubiquitin-dependent responses to replication blocks. Nat. Struct. Mol. Biol. 2012, 19, 1084-1092. [CrossRef] [PubMed]

74. Maskey, R.S.; Flatten, K.S.; Sieben, C.J.; Peterson, K.L.; Baker, D.J.; Nam, H.J.; Kim, M.S.; Smyrk, T.C.; Kojima, Y.; Machida, Y.; et al. Spartan deficiency causes accumulation of Topoisomerase 1 cleavage complexes and tumorigenesis. Nucleic Acids Res. 2017, 45, 4564-4576. [CrossRef] [PubMed]

75. Morocz, M.; Zsigmond, E.; Toth, R.; Enyedi, M.Z.; Pinter, L.; Haracska, L. DNA-dependent protease activity of human Spartan facilitates replication of DNA-protein crosslink-containing DNA. Nucleic Acids Res. 2017, 45, 3172-3188. [CrossRef] [PubMed]

76. Stingele, J.; Bellelli, R.; Alte, F.; Hewitt, G.; Sarek, G.; Maslen, S.L.; Tsutakawa, S.E.; Borg, A.; Kjaer, S.; Tainer, J.A.; et al. Mechanism and regulation of DNA-protein crosslink repair by the DNA-dependent metalloprotease SPRTN. Mol. Cell 2016, 64, 688-703. [CrossRef] [PubMed]

77. Vaz, B.; Popovic, M.; Newman, J.A.; Fielden, J.; Aitkenhead, H.; Halder, S.; Singh, A.N.; Vendrell, I.; Fischer, R.; Torrecilla, I.; et al. Metalloprotease SPRTN/DVC1 orchestrates replication-coupled DNA-protein crosslink repair. Mol. Cell 2016, 64, 704-719. [CrossRef] [PubMed]

78. Nakazato, A.; Kajita, K.; Ooka, M.; Akagawa, R.; Abe, T.; Takeda, S.; Branzei, D.; Hirota, K. SPARTAN promotes genetic diversification of the immunoglobulin-variable gene locus in avian DT40 cells. DNA Repair 2018, 68, 50-57. [CrossRef]

79. Lee, K.Y.; Myung, K. PCNA modifications for regulation of post-replication repair pathways. Mol. Cells 2008, 26, 5-11.

80. McIntyre, J.; Woodgate, R. Regulation of translesion DNA synthesis: Posttranslational modification of lysine residues in key proteins. DNA Repair 2015, 29, 166-179. [CrossRef]

81. Kanao, R.; Masutani, C. Regulation of DNA damage tolerance in mammalian cells by post-translational modifications of PCNA. Mutat. Res. 2017, 803-805, 82-88. [CrossRef]

82. Simpson, L.J.; Ross, A.L.; Szuts, D.; Alviani, C.A.; Oestergaard, V.H.; Patel, K.J.; Sale, J.E. RAD18-independent ubiquitination of proliferating-cell nuclear antigen in the avian cell line DT40. EMBO Rep. 2006, 7, 927-932. [CrossRef] [PubMed] 
83. Okada, T.; Sonoda, E.; Yoshimura, M.; Kawano, Y.; Saya, H.; Kohzaki, M.; Takeda, S. Multiple roles of vertebrate REV genes in DNA repair and recombination. Mol. Cell. Biol. 2005, 25, 6103-6111. [CrossRef] [PubMed]

84. Edmunds, C.E.; Simpson, L.J.; Sale, J.E. PCNA ubiquitination and REV1 define temporally distinct mechanisms for controlling translesion synthesis in the avian cell line DT40. Mol. Cell 2008, 30, 519-529. [CrossRef] [PubMed]

85. Branzei, D.; Seki, M.; Enomoto, T. Rad18/Rad5/Mms2-mediated polyubiquitination of PCNA is implicated in replication completion during replication stress. Genes Cells 2004, 9, 1031-1042. [CrossRef] [PubMed]

86. Hishida, T.; Kubota, Y.; Carr, A.M.; Iwasaki, H. RAD6-RAD18-RAD5-pathway-dependent tolerance to chronic low-dose ultraviolet light. Nature 2009, 457, 612-615. [CrossRef]

87. Hoege, C.; Pfander, B.; Moldovan, G.L.; Pyrowolakis, G.; Jentsch, S. RAD6-dependent DNA repair is linked to modification of PCNA by ubiquitin and SUMO. Nature 2002, 419, 135-141. [CrossRef]

88. Torres-Ramos, C.A.; Prakash, S.; Prakash, L. Requirement of RAD5 and MMS2 for postreplication repair of UV-damaged DNA in Saccharomyces cerevisiae. Mol. Cell. Biol. 2002, 22, 2419-2426. [CrossRef]

89. Branzei, D.; Vanoli, F.; Foiani, M. SUMOylation regulates Rad18-mediated template switch. Nature 2008, 456, 915-920. [CrossRef]

90. Pilzecker, B.; Buoninfante, O.A.; van den Berk, P.; Lancini, C.; Song, J.Y.; Citterio, E.; Jacobs, H. DNA damage tolerance in hematopoietic stem and progenitor cells in mice. Proc. Natl. Acad. Sci. USA 2017, 114, E6875-E6883. [CrossRef]

91. Yang, Y.; Poe, J.C.; Yang, L.; Fedoriw, A.; Desai, S.; Magnuson, T.; Li, Z.; Fedoriw, Y.; Araki, K.; Gao, Y.; et al. Rad18 confers hematopoietic progenitor cell DNA damage tolerance independently of the Fanconi Anemia pathway in vivo. Nucleic Acids Res. 2016, 44, 4174-4188. [CrossRef]

92. Huang, J.; Huen, M.S.; Kim, H.; Leung, C.C.; Glover, J.N.; Yu, X.; Chen, J. RAD18 transmits DNA damage signalling to elicit homologous recombination repair. Nat. Cell Biol. 2009, 11, 592-603. [CrossRef] [PubMed]

93. Motegi, A.; Liaw, H.J.; Lee, K.Y.; Roest, H.P.; Maas, A.; Wu, X.; Moinova, H.; Markowitz, S.D.; Ding, H.; Hoeijmakers, J.H.; et al. Polyubiquitination of proliferating cell nuclear antigen by HLTF and SHPRH prevents genomic instability from stalled replication forks. Proc. Natl. Acad. Sci. USA 2008, 105, 12411-12416. [CrossRef] [PubMed]

94. Motegi, A.; Sood, R.; Moinova, H.; Markowitz, S.D.; Liu, P.P.; Myung, K. Human SHPRH suppresses genomic instability through proliferating cell nuclear antigen polyubiquitination. J. Cell Biol. 2006, 175, 703-708. [CrossRef]

95. Unk, I.; Hajdu, I.; Blastyak, A.; Haracska, L. Role of yeast Rad5 and its human orthologs, HLTF and SHPRH in DNA damage tolerance. DNA Repair 2010, 9, 257-267. [CrossRef]

96. Unk, I.; Hajdu, I.; Fatyol, K.; Szakal, B.; Blastyak, A.; Bermudez, V.; Hurwitz, J.; Prakash, L.; Prakash, S.; Haracska, L. Human SHPRH is a ubiquitin ligase for Mms2-Ubc13-dependent polyubiquitylation of proliferating cell nuclear antigen. Proc. Natl. Acad. Sci. USA 2006, 103, 18107-18112. [CrossRef] [PubMed]

97. Tomi, N.S.; Davari, K.; Grotzky, D.; Loos, F.; Bottcher, K.; Frankenberger, S.; Jungnickel, B. Analysis of SHPRH functions in DNA repair and immunoglobulin diversification. DNA Repair 2014, 24, 63-72. [CrossRef] [PubMed]

98. Kolas, N.K.; Chapman, J.R.; Nakada, S.; Ylanko, J.; Chahwan, R.; Sweeney, F.D.; Panier, S.; Mendez, M.; Wildenhain, J.; Thomson, T.M.; et al. Orchestration of the DNA-damage response by the RNF8 ubiquitin ligase. Science 2007, 318, 1637-1640. [CrossRef] [PubMed]

99. Panier, S.; Durocher, D. Regulatory ubiquitylation in response to DNA double-strand breaks. DNA Repair 2009, 8, 436-443. [CrossRef] [PubMed]

100. Stewart, G.S.; Panier, S.; Townsend, K.; Al-Hakim, A.K.; Kolas, N.K.; Miller, E.S.; Nakada, S.; Ylanko, J.; Olivarius, S.; Mendez, M.; et al. The RIDDLE syndrome protein mediates a ubiquitin-dependent signaling cascade at sites of DNA damage. Cell 2009, 136, 420-434. [CrossRef] [PubMed]

101. Moynahan, M.E.; Chiu, J.W.; Koller, B.H.; Jasin, M. Brca1 controls homology-directed DNA repair. Mol. Cell 1999, 4, 511-518. [CrossRef]

102. Scully, R.; Ganesan, S.; Vlasakova, K.; Chen, J.; Socolovsky, M.; Livingston, D.M. Genetic analysis of BRCA1 function in a defined tumor cell line. Mol. Cell 1999, 4, 1093-1099. [CrossRef] 
103. Zhao, G.Y.; Sonoda, E.; Barber, L.J.; Oka, H.; Murakawa, Y.; Yamada, K.; Ikura, T.; Wang, X.; Kobayashi, M.; Yamamoto, K.; et al. A critical role for the ubiquitin-conjugating enzyme Ubc13 in initiating homologous recombination. Mol. Cell 2007, 25, 663-675. [CrossRef] [PubMed]

104. Kobayashi, S.; Keka, I.S.; Guilbaud, G.; Sale, J.; Narita, T.; Abdel-Aziz, H.I.; Wang, X.; Ogawa, S.; Sasanuma, H.; Chiu, R.; et al. The role of HERC2 and RNF8 ubiquitin E3 ligases in the promotion of translesion DNA synthesis in the chicken DT40 cell line. DNA Repair 2016, 40, 67-76. [CrossRef]

105. Arakawa, H.; Hauschild, J.; Buerstedde, J.M. Requirement of the activation-induced deaminase (AID) gene for immunoglobulin gene conversion. Science 2002, 295, 1301-1306. [CrossRef]

106. Oka, H.; Sakai, W.; Sonoda, E.; Nakamura, J.; Asagoshi, K.; Wilson, S.H.; Kobayashi, M.; Yamamoto, K.; Heierhorst, J.; Takeda, S.; et al. DNA damage response protein ASCIZ links base excision repair with immunoglobulin gene conversion. Biochem. Biophys. Res. Commun. 2008, 371, 225-229. [CrossRef] [PubMed]

107. Budzynska, P.M.; Kylaniemi, M.K.; Kallonen, T.; Soikkeli, A.I.; Nera, K.P.; Lassila, O.; Alinikula, J. Bach2 regulates AID-mediated immunoglobulin gene conversion and somatic hypermutation in DT40 B cells. Eur. J. Immunol. 2017, 47, 993-1001. [CrossRef] [PubMed]

108. Kikuchi, K.; Abdel-Aziz, H.I.; Taniguchi, Y.; Yamazoe, M.; Takeda, S.; Hirota, K. Bloom DNA helicase facilitates homologous recombination between diverged homologous sequences. J. Biol. Chem. 2009, 284, 26360-26367. [CrossRef] [PubMed]

109. Conticello, S.G.; Ganesh, K.; Xue, K.; Lu, M.; Rada, C.; Neuberger, M.S. Interaction between antibody-diversification enzyme AID and spliceosome-associated factor CTNNBL1. Mol. Cell 2008, 31, 474-484. [CrossRef]

110. Kitao, H.; Kimura, M.; Yamamoto, K.; Seo, H.; Namikoshi, K.; Agata, Y.; Ohta, K.; Takata, M. Regulation of histone $\mathrm{H} 4$ acetylation by transcription factor E2A in Ig gene conversion. Int. Immunol. 2008, 20, 277-284. [CrossRef] [PubMed]

111. Pace, P.; Mosedale, G.; Hodskinson, M.R.; Rosado, I.V.; Sivasubramaniam, M.; Patel, K.J. Ku70 corrupts DNA repair in the absence of the Fanconi anemia pathway. Science 2010, 329, 219-223. [CrossRef]

112. Kitao, H.; Nanda, I.; Sugino, R.P.; Kinomura, A.; Yamazoe, M.; Arakawa, H.; Schmid, M.; Innan, H.; Hiom, K.; Takata, M. FancJ/Brip1 helicase protects against genomic losses and gains in vertebrate cells. Genes Cells 2011, 16, 714-727. [CrossRef] [PubMed]

113. Kikuchi, K.; Taniguchi, Y.; Hatanaka, A.; Sonoda, E.; Hochegger, H.; Adachi, N.; Matsuzaki, Y.; Koyama, H.; van Gent, D.C.; Jasin, M.; et al. Fen-1 facilitates homologous recombination by removing divergent sequences at DNA break ends. Mol. Cell. Biol. 2005, 25, 6948-6955. [CrossRef] [PubMed]

114. Lin, W.; Hashimoto, S.; Seo, H.; Shibata, T.; Ohta, K. Modulation of immunoglobulin gene conversion frequency and distribution by the histone deacetylase HDAC2 in chicken DT40. Genes Cells 2008, 13, 255-268. [CrossRef] [PubMed]

115. Simpson, L.J.; Sale, J.E. UBE2V2 (MMS2) is not required for effective immunoglobulin gene conversion or DNA damage tolerance in DT40. DNA Repair 2005, 4, 503-510. [CrossRef] [PubMed]

116. Campo, V.A.; Patenaude, A.M.; Kaden, S.; Horb, L.; Firka, D.; Jiricny, J.; Di Noia, J.M. MSH6- or PMS2-deficiency causes re-replication in DT40 B cells, but it has little effect on immunoglobulin gene conversion or on repair of AID-generated uracils. Nucleic Acids Res. 2013, 41, 3032-3046. [CrossRef]

117. Nakahara, M.; Sonoda, E.; Nojima, K.; Sale, J.E.; Takenaka, K.; Kikuchi, K.; Taniguchi, Y.; Nakamura, K.; Sumitomo, Y.; Bree, R.T.; et al. Genetic evidence for single-strand lesions initiating Nbs1-dependent homologous recombination in diversification of Ig V in chicken B lymphocytes. PLoS Genet. 2009, 5, e1000356. [CrossRef] [PubMed]

118. Paddock, M.N.; Buelow, B.D.; Takeda, S.; Scharenberg, A.M. The BRCT domain of PARP-1 is required for immunoglobulin gene conversion. PLoS Biol. 2010, 8, e1000428. [CrossRef] [PubMed]

119. Hosono, Y.; Abe, T.; Ishiai, M.; Islam, M.N.; Arakawa, H.; Wang, W.; Takeda, S.; Ishii, Y.; Takata, M.; Seki, M.; et al. Tumor suppressor RecQL5 controls recombination induced by DNA crosslinking agents. Biochim. Biophys. Acta 2014, 1843, 1002-1012. [CrossRef] [PubMed]

120. Simpson, L.J.; Sale, J.E. Rev1 is essential for DNA damage tolerance and non-templated immunoglobulin gene mutation in a vertebrate cell line. EMBO J. 2003, 22, 1654-1664. [CrossRef] [PubMed]

(C) 2018 by the authors. Licensee MDPI, Basel, Switzerland. This article is an open access article distributed under the terms and conditions of the Creative Commons Attribution (CC BY) license (http:/ / creativecommons.org/licenses/by/4.0/). 